\title{
INVESITIGASI PENGARUH DISIPLIN KERJA GURU DAN MOTIVASI BELAJAR SISWA TERHADAP PRESTASI BELAJAR SISWA DI SALAH SATU SEKOLAH MENENGAH PERTAMA NEGERI
}

\author{
Krista Renggana \\ SMP Negeri 1 Jatibarang Indramayu-Jawa Barat, kristarenggana3081986@gmail.com
}

Received January 7, 2020, reviewed februari 20, 2020, published Maret 30, 2020

Citation: Renggana, K. (2020). Invesitigasi Pengaruh Disiplin Kerja Guru Dan Motivasi Belajar Siswa Terhadap Prestasi Belajar Siswa Di Salah Satu Sekolah Menengah Pertama Negeri. Edum Journal, $3(1)$

\begin{abstract}
ABSTRAK
Tujuan penelitian ini adalah untuk menginvestigasi pengaruh disiplin kerja guru dan motivasi belajar siswa terhadap prestasi belajar siswa. Desain penelitian yang digunakan yakni desain ex post facto tipe causal komparatif. Teknik pengumpulan data terhadap disiplin kerja guru, motivasi belajar siswa menggunakan angket skala Likert. Sedangkan prestasi belajar siswa diperoleh dari hasil ujia akhir sekolah. Partisipan yang terlibat yakni 44 orang guru sekolah dan 44 orang siswa. Sedangkan analisis data menggunakan teknik analisis regresi berganda. Berdasarkan hasil penelitian dapat disimpulkan bahwa: (1) Terdapat pengaruh yang positif dan signifikan disiplin kerja guru terhadap prestasi belajar siswa di salah satu SMP Negeri di Kabupaten Indramayu. Adapun besaran pengaruhnya mencapai $36,1 \%$. (2) Terdapat pengaruh yang positif tetapi tidak signifikan motivasi belajar siswa terhadap prestasi belajar siswa di salah satu SMP Negeri di Kabupaten Indramayu. Adapun besaran pengaruhnya hanya $3,1 \%$. (3) Terdapat pengaruh yang positif dan signifikan disiplin kerja guru dan motivasi belajar siswa secarasimultan terhadap prestasi belajar siswa di salah satu SMP Negeri di Kabupaten Indramayu. Adapun besaran pengaruhnya mencapai 39,3\%. Beranjak dari hasil kajian tersebut, hendaknya disiplin kerja guru mendapat perhatian yang serius untuk dioptimalkan terutama menyangkut ketertiban dalam melaksanakan kegiatan. Baik kegiatan akademik maupun kegiatan non akademik diharapkan lebih tertib dan teratur melalui persiapan dan perencanaan yang sesuai tujuan dari kegiatan.
\end{abstract}

Kata Kunci: Disiplin Kerja Guru, Motivasi Belajar, Prestasi Belajar

\begin{abstract}
The purpose of this study is to investigate the effect of teacher work discipline and student motivation on student achievement. The research design used is the comparative ex post facto causal type design. Data collection techniques on teacher work discipline, student motivation to use Likert scale questionnaire. While student achievement is obtained from the results of the final school examination. Participants involved were 44 school teachers and 44 students. While the data analysis uses multiple regression analysis techniques. Based on the results of the study it can be concluded that: (1) There is a positive and significant influence of teacher work discipline on student achievement in one of the State Junior High Schools in Indramayu Regency. The magnitude of the effect reached $36.1 \%$. (2) There is a positive but not significant influence on students' learning motivation on student achievement in one of the State Junior High Schools in Indramayu Regency. The magnitude of the effect is only $3.1 \%$. (3) There is a positive and significant influence of teacher's work discipline and simultaneous student learning motivation on student achievement in one of the State Junior High Schools in Indramayu Regency. The magnitude of the effect reached 39.3\%. Moving on from the results of the study, teacher's work discipline should receive serious attention to be optimized, especially regarding orderliness in carrying out activities. Both academic activities and non-academic activities are expected to be more orderly and organized through preparation and planning in accordance with the objectives of the activity.
\end{abstract}

Keywords: Teacher Work Discipline, Learning Motivation, Learning Achievement 
Salah satu tolak ukur keberhasilan di dalam proses pembelajaran dalam ruang lingkup sekolah yakni prestasi belajar siswa. Sudirman (2015) mengatakan bahwa prestasi belajar berkaitan erat dengan penguasaan materi tertentu. Selain itu, prestasi belajar merupakan hasil belajar yang dicapai setelah melalui proses kegiatan belajar mengajar (Syafi'i, Marfiyanto \& Rodiyah, 2018). Prestasi belajar dapat ditunjukkan melalui nilai yang diberikan oleh seorang guru dari jumlah bidang studi yang telah dipelajari oleh peserta didik (Syafi'i, Marfiyanto \& Rodiyah, 2018).

Salah satu kunci menumbuhkan prestasi belajar yakni guru. Guru adalah pendidik professional dengan tugas utama mendidik dan mengevaluasi peserta didik, pada pendidikan anak usia dini jalur pendidikan formal, pendidikan dasar dan pendidikan menengah. Dalam informasi tentang wawasan wiyata mandala, kedisiplinan guru diartikan sebagai sikap mental yang mengandung kerelaan, peraturan dan norma yang berlaku dalam menunaikan tugas dan tanggung jawab (Wibowo, 2012:85).

Kedisiplinan guru menjadi sangat berarti bagi keberhasilan seorang guru dalam mengajar dan kemajuan sekolah serta meningkatkan prestasi belajar siswa (Nashir, 2016). Pengertian diatas dapat dipahami bahwa kedisiplinan guru merupakan sikap penuh kerelaan dalam mematuhi semua aturan dan norma yang ada dalam menjalankan tugasnya sebagai bentuk tanggung jawabnya terhadap pendidikan anak didiknya.

Tugas guru dalam pembelajaran tidak terbatas pada penyampaian materi pembelajaran, tetapi lebih dari itu, guru harus membentuk kompetensi dan pribadi peserta didik, terutama pada jam-jam sekolah, agar tidak terjadi penyimpangan perilaku atau tindakan yang indisiplin. Untuk kepentingan tersebut, dalam rangka mendisiplinkan peserta didik guru harus mampu menjadi pembimbing, contoh atau teladan, pengawas dan pengendali seluruh perilaku peserta didik (Mulyasa, 2007:126).

Sebagai pembimbing guru harus berupaya untuk membimbing dan mengarahkan perilaku peserta didik kearah yang positif, dan menunjang pembelajaran. Sebagai contoh atau teladan, guru harus memperlihatkan perilaku disiplin yang baik kepada peserta didik, karena bagaimana peserta didik akan berdisiplin sedangkan gurunya tidak menunjukkan sikap disiplin. Sebagai pengawas,guru harus senantiasa mengawasi seluruh perilaku peserta didik, terutama pada jamjam efektif sekolah, sehingga kalua terjadi pelanggaran terhadap disiplin, dapat segera 
diatasi. Sebagai pengendali, guru harus mampu mengendalikan seluruh perilaku peserta didik disekolah. Dalam hal ini guru harus mampu secara efektif menggunakan alat pendidikan secara tepat waktu dan tepat sasaran, baik dalam memberikan hadiah maupun hukuman terhadap peserta didik (Mulyasa, 2007:126).

Berdasarkan penelitian-penelitian yang relevan seperti (1) Amalda \& Prasojo (2018) hasil penelitian ini adalah sebagai berikut: (1) terdapat pengaruh antara motivasi kerja guru terhadap prestasi belajar siswa SMA/MA di Kota Mataram sejumlah $13,1 \%$; (2) terdapat pengaruh antara disiplin kerja guru terhadap prestasi belajar siswa SMA/MA di Kota Mataram sejumlah 9,9\%; (3) terdapat pengaruh antara kedisiplinan siswa terhadap prestasi belajar siswa SMA/MA di Kota Mataram sejumlah 7,8\%; (4) motivasi kerja guru, disiplin kerja guru dan kedisiplinan siswa secara bersama-sama mempengaruhi prestasi belajar siswa SMA/MA di Kota Mataram sejumlah 34\%. (2) Vani (2015) Adanya pengaruh positf dan signifikan antara disiplin kerja guru dan motivasi belajar terhadap hasil belajar siswa kelas VIII di SMP Negeri 8 Padang. (3) Prasasty (2017) hasil penelitian ini adalah: (1) terdapat pengaruh yang signifikan antara motivasi terhadap prestasi belajar Matematika; (2) terdapat pengaruh yang signifikan antara disiplin dan belajar prestasi belajar Matematika; (3) terdapat yang signifikan antara motivasi dan disiplin belajar secara bersama-sama terhadap prestasi belajar Matematika.

Berdasarkan penelitian-penelitian tersebut, peran kedisiplinan dan motivasi merupakan merupakan factor yang mempengaruhi hasil belajar yang berasal dari luar individu (ekstern). Hanya saja, penelitian yang diungkap belum tentu sama dengan penelitian yang diungkap dalam penelitian ini. Oleh sebab itu, penelitian ini bertujuan untuk menginvestigasi pengaruh kedisiplinan guru dan motivasi terhadap prestasi belajar siswa.

\section{METODE PENELITIAN}

Pendekatan penelitian yang digunakan dalam penelitian ini adalah kuantitatif. Penelitian kuntitatif adalah penelitian yang pada dasarnya menggunakan pendekatan deduktif, artinya pendekatan yang berangkat dari suatu kerangka teori, gagasan para ahli, maupun pemahaman peneliti berdasarkann pengalamannya, kemudian dikembangkan menjadi permasalahan beserta pemecahan yang diajukan untuk memperoleh pembenaran (verifikasi) dalam bentuk dukungan data empiris di lapangan (Tanzeh, 2011:64). Sedangkan desain yang digunakan yakni ex post facto tipe 
korelasional. Penelitian ini ditujukkan untuk mengetahui hubungan suatu variabel dengan variabel-variabel lain. Hubungan antara satu dengan beberapa variabel lain dinyatakan dengan besarnya koefisien korelasi dan keberartian (signifikansi) secara statistik (Sukmadinata, 2009:56). Dalam penelitian ini setiap variabel dicari korelasi (hubungannya), yakni antara variabel bebas (disiplin kerja guru, motivasi belajar siswa) terhadap variabel terikat (prestasi belajar siswa).

Tabel 1 Kisi - kisi Instrumen Variabel Disiplin Guru

\begin{tabular}{ccl}
\hline Variabel & \multicolumn{1}{c}{ Dimensi } & \multicolumn{1}{c}{ Indikator } \\
\hline \multirow{2}{*}{ Disiplin Guru $\left(\mathbf{X}_{\mathbf{1}}\right)$} & Disiplin Preventif & $\begin{array}{l}\text { Sikap guru terhadap disiplin kerja } \\
\text { Disiplin pada proses pembelajaran } \\
\text { (Prijodarminto, 2000) }\end{array}$ \\
& Disiplin Korektif & $\begin{array}{l}\text { Disiplin terhadap tugas pokok } \\
\text { Ketertiban Kegiatan }\end{array}$ \\
\hline
\end{tabular}

Tabel 2 Kisi - kisi Instrumen Variabel Motivasi Belajar

\begin{tabular}{|c|c|}
\hline $\begin{array}{c}\text { Motivasi Belajar } \\
\left(\mathbf{X}_{2}\right)(\text { Siagian, 2003) }\end{array}$ & $\begin{array}{l}\text { Kepribadian } \\
\text { Sikap } \\
\text { Pengalaman dan pendidikan } \\
\text { Berbagai harapan } \\
\text { Cita-cita } \\
\text { Dorongan dari guru } \\
\text { Dorongan dari keluarga } \\
\text { Dorongan dari lingkungan sekitar }\end{array}$ \\
\hline 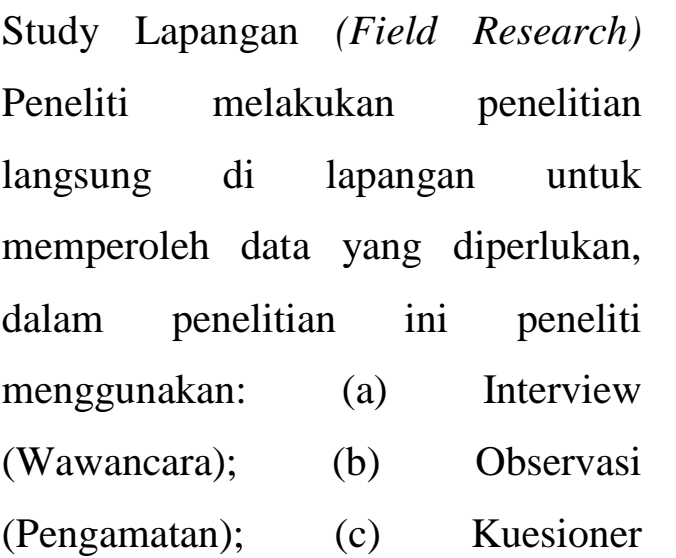 & $\begin{array}{l}\text { (Angket). Teknik analisis data yang } \\
\text { digunakan yakni teknik Analisis } \\
\text { Deskritif dan inferensial. Analisis } \\
\text { infersensial yang digunakan } \\
\text { menggunakan Korelasi Koefisien } \\
\text { Sederhana (persial dan Analisis } \\
\text { Korelasi Koefisien Ganda (simultan). }\end{array}$ \\
\hline
\end{tabular}

\section{HASIL PENELITIAN}

Fokus utama pada penelitian ini adalah untuk mengetahui besaran pengaruh Disiplin Guru dan Motivasi Belajar Siswa terhadap Prestasi Belajar
Peserta Didik. Untuk mengetahui besaran pengaruh variable Disiplin guru $\left(\mathrm{X}_{1}\right)$ terhadap prestasi peserta didik dilakukan dengan uji regresi liner dengan SPSS versi 23. 
Untuk mengetahui besaran dengan kriteria pengujian jika tingkat pengaruh disiplin kerja guru $\left(\mathrm{X}_{1}\right)$ secara signifikansi lebih kecil dari 0,05, maka individual (parsial) terhadap prestasi hipotesis diterima. Adapun hasil belajar siswa (Y) dapat dilihat dari nilai pengujian hipotesis tersebut adalah t pada tabel Coefficients dibawah ini sebagai berikut:

Tabel 1 Uji Hipotesis Variabel $X_{1}$ terhadap $Y$

Coefficients $^{\mathrm{a}}$

\begin{tabular}{|c|c|c|c|c|c|c|}
\hline \multirow[b]{2}{*}{ Model } & & \multicolumn{2}{|c|}{$\begin{array}{c}\text { Unstandardized } \\
\text { Coefficients }\end{array}$} & \multirow{2}{*}{ 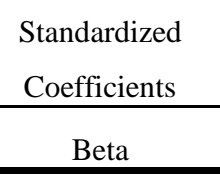 } & \multirow[t]{2}{*}{$\mathrm{t}$} & \multirow[t]{2}{*}{ Sig. } \\
\hline & & B & Std. Error & & & \\
\hline 1 & (Constant) & 29.380 & 7.286 & & 4.032 & .000 \\
\hline & Disiplin_Kerja_Guru_X1 & .546 & .112 & .601 & 4.869 & .000 \\
\hline
\end{tabular}

Berdasarkan tabel hasil salah satu SMP Negeri di Kabupaten perhitungan dengan SPSS 23 Indramayu".

diperoleh bahwa disiplin kerja guru Persamaan regresi $\hat{y}=a+b x_{1}$ $\left(\mathrm{X}_{1}\right)$ memiliki nilai sebesar $p$-value dari hasil perhitungan diperoleh $\hat{y}=$ $0,000<0,05$ artinya berdistribusi $29,380+0,546 \mathrm{X}_{1}$. Konstanta sebesar signifikan. Hal tersebut berarti disiplin kerja guru $\left(\mathrm{X}_{1}\right)$ secara parsial 29,380 menyatakan bahwa jika ada berpengaruh terhadap prestasi belajar siswa (Y). Hal tersebut memiliki makna menerima hipotesis yang menyatakan: "Terdapat pengaruh positif dan signifikan disiplin kerja guru terhadap prestasi belajar siswa kenaikan nilai dari variabel disiplin kerja guru $\left(\mathrm{X}_{1}\right)$, maka prestasi belajar siswa (Y) adalah 29,380. Koefesien regresi sebesar 0,546 menyatakan bahwa setiap perubahan satu skor atau nilai disiplin kerja guru akan memberikan skor 0,546.

Tabel 2 Besaran Pengaruh Variabel $\mathrm{X}_{1}$ terhadap $\mathrm{Y}$

\begin{tabular}{|c|r|r|r|r|}
\hline & & & & \\
Model & $\mathrm{R}$ & R Square & Adjusted R Square & \multicolumn{1}{c|}{$\begin{array}{c}\text { Std. Error of the } \\
\text { Estimate }\end{array}$} \\
\hline 1 & $.601^{\mathrm{a}}$ & .361 & .346 & 4.166 \\
\hline
\end{tabular}

a. Predictors: (Constant), Disiplin_Kerja_Guru_X1 
Dari tabel di atas terlihat bahwa $R$ Square sebesar 0,361 , hal ini berarti bahwa $0,361 \times 100 \%=36,1 \%$ prestasi belajar siswa dipengaruhi oleh variabel disiplin kerja guru, sedangkan sisanya $63,9 \%$ dipengaruhi oleh faktor lain yang tidak diteliti.

Tabel 3 Uji Hipotesis Variabel $\mathrm{X}_{2}$ terhadap $Y$

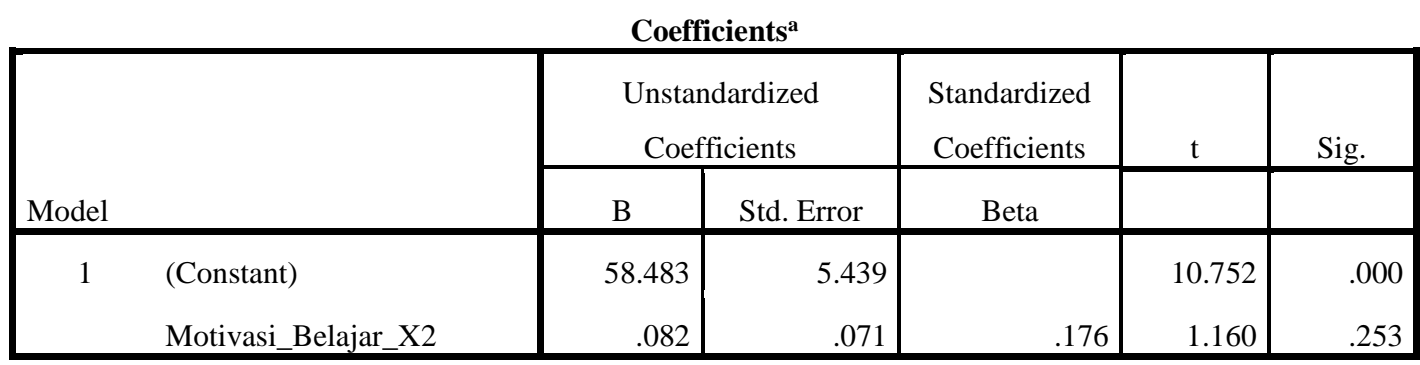

a. Dependent Variable: Prestasi_Belajar_Siswa_Y

Berdasarkan tabel hasil demikian motivasi belajar siswa $\left(\mathrm{X}_{2}\right)$ perhitungan dengan SPSS 23 diperoleh secara parsial tidak berpengaruh bahwa motivasi belajar siswa $\left(\mathrm{X}_{2}\right)$ terhadap prestasi belajar siswa (Y). memiliki nilai sebesar $p$-value $0,253<$.

0,05 artinya tidak signifikan. Dengan

Tabel 4 Besaran Pengaruh Variabel $\mathrm{X}_{2}$ terhadap $\mathrm{Y}$

\begin{tabular}{|c|r|r|r|r|}
\hline & & & & \multicolumn{2}{c|}{ Model Summary } \\
Model & $\mathrm{R}$ & R Square & Adjusted R Square & \multicolumn{1}{c|}{ Estimate } \\
\hline 1 & $.176^{\mathrm{a}}$ & .031 & .008 & 5.130 \\
\hline
\end{tabular}

a. Predictors: (Constant), Motivasi_Belajar_X2

Dari tabel di atas terlihat bahwa $R \quad$ variabel motivasi belajar siswa, Square sebesar 0,031, hal ini berarti sedangkan sisanya 96,9\% dipengaruhi bahwa $0,031 \times 100 \%=3,1 \%$ prestasi oleh faktor lain yang tidak diteliti. belajar siswa dipengaruhi oleh 
Tabel 5 Uji Hipotesis Variabel $X_{1}$ dan $X_{2}$ terhadap $Y$

\begin{tabular}{|c|c|c|c|c|c|c|}
\hline \multicolumn{7}{|c|}{ Coefficients $^{\mathrm{a}}$} \\
\hline \multirow[b]{2}{*}{ Model } & & \multicolumn{2}{|c|}{$\begin{array}{c}\text { Unstandardized } \\
\text { Coefficients }\end{array}$} & $\begin{array}{l}\text { Standardized } \\
\text { Coefficients }\end{array}$ & $\mathrm{t}$ & Sig. \\
\hline & & $\mathrm{B}$ & Std. Error & Beta & & \\
\hline 1 & (Constant) & 22.973 & 8.401 & & 2.735 & .009 \\
\hline & Disiplin_Kerja_Guru_X1 & & .111 & .602 & & .000 \\
\hline & Motivasi_Belajar_X2 & .083 & .057 & .179 & 1.473 & .148 \\
\hline
\end{tabular}

a. Dependent Variable: Prestasi_Belajar_Siswa_Y

Berdasarkan tabel hasil uji $\mathrm{t}$ belajar siswa salah satu SMP Negeri di diperoleh bahwa variabel disiplin kerja Kabupaten Indramayu”.

guru $\left(\mathrm{X}_{1}\right)$ dan motivasi belajar siswa

Untuk mengetahui persamaan $\left(\mathrm{X}_{2}\right)$ secara bersama-sama (simultan) regresi dapat dilihat dari tabel di atas. memiliki nilai sebesar p-value 0,009 < Berdasarkan tabel tersebut 0,05 artinya signifikan. Dengan menunjukkan persamaan regresi linier demikian disiplin kerja guru $\left(\mathrm{X}_{1}\right)$ dan ganda: $\hat{y}=22,973+0,546 \mathrm{X}_{1}+0,083 \mathrm{X}_{2}$. motivasi belajar siswa $\left(\mathrm{X}_{2}\right)$ secara Persamaan tersebut menyatakan bahwa bersama-sama (simultan) berpengaruh setiap penambahan $X_{1}$ dan $X_{2}$ sebesar 1 terhadap prestasi belajar siswa (Y). Hal maka akan meningkatkan $\mathrm{Y}$ sebesar tersebut membuktikan diterimanya 0,546 dan 0,083 , artinya setiap hipotesis yang menyatakan: "Terdapat peningkatan disiplin kerja guru dan pengaruh positif dan signifikan disiplin motivasi belajar siswa sebesar 1, akan kerja guru dan motivasi belajar siswa meningkatkan prestasi belajar siswa secara bersama-sama terhadap prestasi sebesar 0,546 dan 0,083.

Tabel 6 Besaran Pengaruh Variabel $X_{1}$ dan $X_{2}$ terhadap $Y$

\begin{tabular}{|c|r|r|r|c|}
\hline & & & & \multicolumn{2}{c|}{ Model Summary } \\
Model & $\mathrm{R}$ & R Square & Adjusted R Square & \multicolumn{1}{c|}{ Estimate of the } \\
\hline 1 & $.627^{\mathrm{a}}$ & .393 & .363 & 4.110 \\
\hline
\end{tabular}

a. Predictors: (Constant), Motivasi_Belajar_X2, Disiplin_Kerja_Guru_X1 
Dari tabel di atas terlihat bahwa $R$ Square sebesar 0,393, hal ini berarti bahwa $0,393 \times 100 \%=39,3 \%$ prestasi belajar siswa dipengaruhi oleh variabel disiplin kerja guru dan motivasi belajar siswa secara simultan, sedangkan sisanya $60,7 \%$ dipengaruhi faktor lain yang tidak diteliti

\section{PEMBAHASAN}

Permasalahan yang ingin dijawab dalam penelitian ini adalah adakah pengaruh pelaksanaan disiplin kerja guru terhadap prestasi belajar siswa salah satu SMP Negeri di Kabupaten Indramayu. Secara empirik, hasil penelitian ini menginformasikan yang pertama terdapat pengaruh yang signifikan disiplin kerja guru terhadap prestasi belajar siswa.

Hasil tersebut sejalan dengan hasil penelitiannya Bariroh (2015) yang menyimpulkan bahwa kedisiplinan kerja guru mempengaruhi prestasi belajar siswa, karena terdapat hubungan sebesar 0,786 atau 78,6\% yang tergolong sangat kuat berdasarkan tingkat keeratannya. Selain itu, penelitian ini juga sejalan dengan Naser (2012) setelah dilakukan uji korelasi ternyata ada hubungannya disiplin kerja guru dengan tingkat prestasi belajar siswa Namun demikian prestasi belajar siswa pada salah satu SMP Negeri di Kabupaten Indramayu ini tersebut tidak hanya dipengaruhi oleh disiplin kerja guru saja, ada faktor lain (epsilon), selain motivasi belajar siswa, yang juga berpengaruh, yang tidak dikaji dalam penelitian ini. Jim (2002:54) mengatakan bahwa: "Disiplin berarti kerja keras. Mereka yang berhasil menuntaskan pekerjaan, sekalipun pekerjaan itu tidak menyenangkan, telah mengembangkan sebuah ketangguhan mental yang berasal dari praktek, kesabaran dan kemampuan untuk melihat sesuatu yang lebih berharga di balik tugas-tugas di depan mata. Disiplin diri menyangkut apa yang perlu dilakukan, bukan apa yang ingin dilakukan”.

Selain itu terkait motivasi belajar siswa, berdasarkan hasil penelitian ini menginformasikan tidak terdapat pengaruh motivasi belajar siswa terhadap prestasi belajar siswa salah satu SMP Negeri di Kabupaten Indramayu. Hasil penelitian ini berbeda dengan penelitian sebelumnnya seperti Winata \& Friantini (2019) menyimpulk Hasil penelitian menunjukkan terdapat pengaruh motivasi belajar terhadap prestasi belajar matematika siswa kelas VIII SMP Negeri 1 Kuala Behe Tahun Ajaran 2018/2019 Kabupaten Landak.

Berdasarkan temuan empirik yang menunjukkan adanya pengaruh yang signifikan disiplin kerja guru dan motivasi belajar siswa secara simultan terhadap 
prestasi belajar siswa. Kontribusi yang diberikan oleh disiplin kerja guru dan motivasi belajar siswa secara bersamasama terhadap prestasi belajar siswa salah satu SMP Negeri di Kabupaten Indramayu adalah sebesar $39,3 \%$, sementara sisanya dipengaruhi oleh variabel lain, yang tidak dikaji dalam penelitian ini (epsilon).

\section{KESIMPULAN}

Berdasarkan hasil penelitian dapat disimpulkan bahwa: (1) Terdapat pengaruh yang positif dan signifikan disiplin kerja guru terhadap prestasi belajar siswa di salah satu SMP Negeri di Kabupaten Indramayu. Adapun besaran pengaruhnya mencapai $36,1 \%$.

Terdapat pengaruh yang positif tetapi tidak signifikan motivasi belajar siswa terhadap prestasi belajar siswa di salah satu SMP Negeri di Kabupaten Indramayu. Adapun besaran pengaruhnya hanya $3,1 \%$. (3) Terdapat pengaruh yang positif dan signifikan disiplin kerja guru dan motivasi belajar siswa secarasimultan terhadap prestasi belajar siswa di salah satu SMP Negeri di Kabupaten Indramayu. Adapun besaran pengaruhnya mencapai 39,3\%.

\section{DAFTAR PUSTAKA}

Amalda, N., \& Prasojo, L. D. (2018). Pengaruh motivasi kerja guru, disiplin kerja guru, dan kedisiplinan siswa terhadap prestasi belajar siswa. Jurnal Akuntabilitas Manajemen Pendidikan,6(1), 1121.

Bariroh, S. (2015). Analisis Pengaruh Kedisiplinan Kerja Guru Terhadap Prestasi Belajar Siswa Pada Sma Negeri 1 Bumiayu Kabupaten Brebes. Jurnal Kependidikan,3(2), 33-51.

Jim, C. (1998). Motivation and Goal Setting.

Mulyasa, E. 2007. Menjadi Guru Profesional menciptakan Pembelajaran Kreatif dan Menyenangkan. Bandung: Rosdakarya

Naser, A. (2012). Analisis Pengaruh Disiplin Kerja Guru Terhadap Prestasi Anak Didik Pada SLTP Negeri 1 Tanjung Bintang. Jurnal Organisasi dan Manajemen, 2(1), 1-9.

Nashir, A. (2016). Pengaruh kedisiplinan guru terhadap prestasi belajar. TARBAWI: Jurnal Pendidikan Agama Islam, 1(1), 2128.

Prasasty, A. T. (2017). Pengaruh disiplin dan motivasi belajar terhadap prestasi belajar matematika siswa kelas X SMK Bina Karya Insan Tangerang Selatan. Utility, 1(1), 6574.

Prijodarminto, S. (2000), Disiplin Kiat Menuju Sukses. Jakarta: PT. Pradnya Paramita.

Siagian S.P. (2003). Teori Motivasi dan Aplikasinya. Jakarta: Rineka Cipta

Sudirman. (2015). Pengaruh Pembelajaran Giving Question and Getting Answer Terhadap Prestasi Belajar Siswa. Gema Wiralodra, Vol 7, No 1.

Syafi'i, A., Marfiyanto, T., \& Rodiyah, S. K. (2018). Studi Tentang Prestasi Belajar Siswa Dalam Berbagai Aspek Dan Faktor Yang 
Mempengaruhi. Jurnal Komunikasi Pendidikan, 2(2), 115-123

Sukmadinata, N.S. (2009). Metode penelitian Pendidikan. Bandung: Remaja Rosdakarya.

Tanzeh, A. (2011). Metodologi Penelitian Praktis. Yogyakarta: Teras.Amalda, N., \& Prasojo, L. D. (2018). Pengaruh motivasi kerja guru, disiplin kerja guru, dan kedisiplinan siswa terhadap prestasi belajar siswa. Jurnal Akuntabilitas Manajemen Pendidikan, 6(1), 1121.

Vani, S. (2015). Analisis Disiplin Kerja Guru dan Motivasi Belajar terhadap Prestasi Belajar Siswa pada Mata Pelajaran IPS Kelas VIII di SMP N 8 Padang. Economica: Jurnal Program Studi Pendidikan Ekonomi STKIP PGRI Sumatera Barat, 4(1), 102-108.

Winata, R., \& Friantini, R. N. (2019). Pengaruh motivasi belajar terhadap prestasi belajar matematika siswa kelas VIII SMP negeri 1 Kuala Behe. Jurnal Math Educator Nusantara: Wahana Publikasi Karya Tulis Ilmiah Di Bidang Pendidikan Matematika, 5(01), 4350.

Pendidikan. Jakarta : PT. Raja Grafindo Persada. 